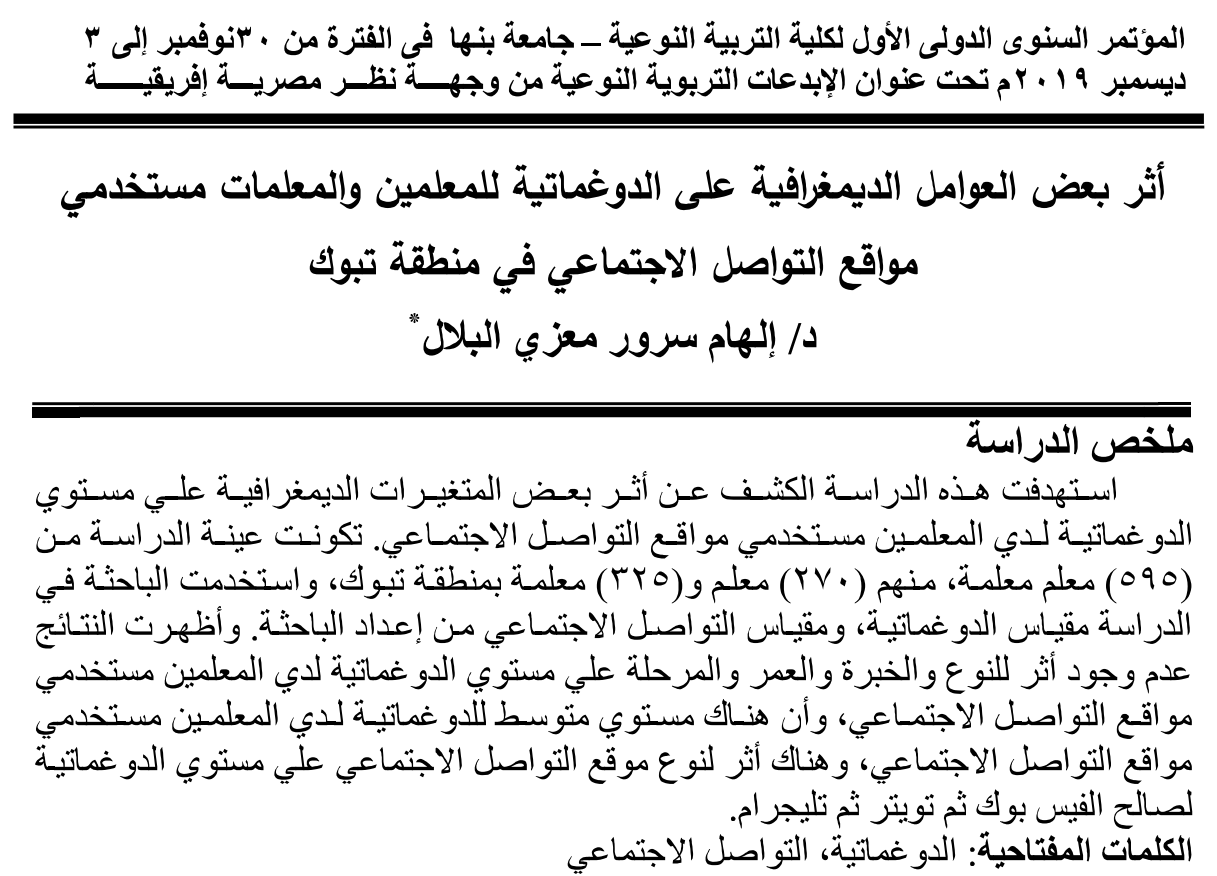

\title{
Summary
}

This study aimed to reveal the impact of some demographic variables on the level of dogmatism among teachers and users of social networking sites. The sample of the study consisted of $(090)$ teachers, of whom ( $Y V \cdot$ ) teachers and ( $\left.r Y_{0}\right)$ teachers in Tabuk region. The researcher used the dogmatic scale and the social communication scale prepared by the researcher. The results showed that there is no effect of gender, experience, age and stage on the level of dogmatism among teachers of social media users, and there is an average level of dogmatism among teachers' users of social networking sites, and there is an impact of the type of social networking site on the level of dogmatism in favor of Facebook, Twitter and then Telegram.

Keywords: Dogmatic, Social Communication

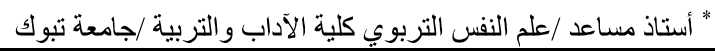

$|r|$

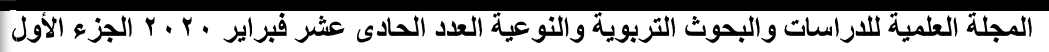




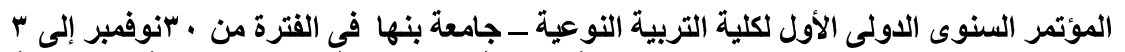

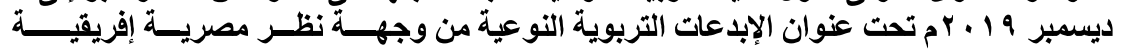

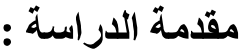

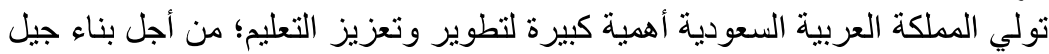

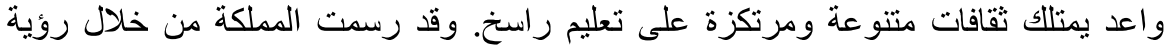

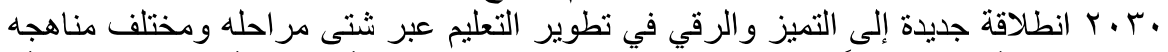

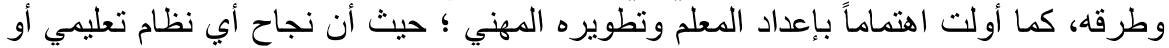

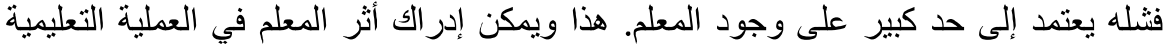

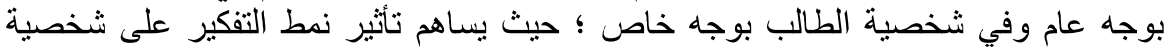

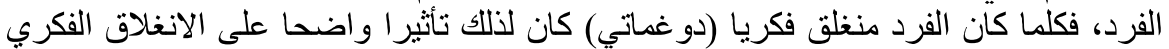

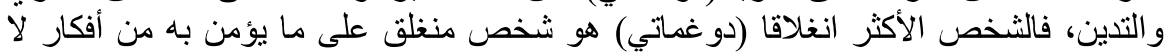

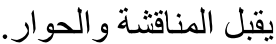

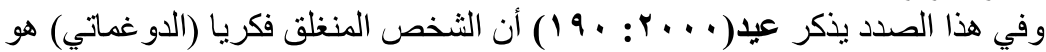

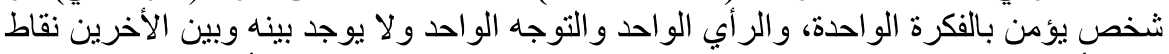

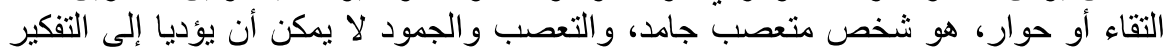

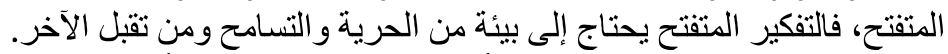

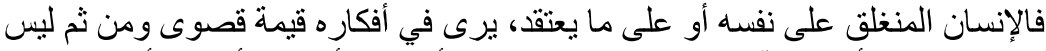

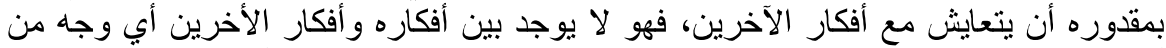

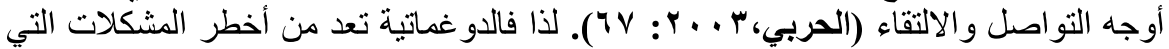

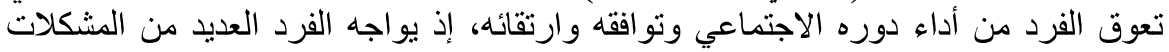

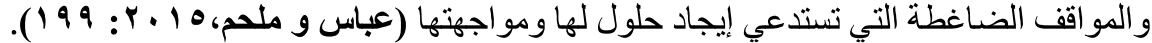

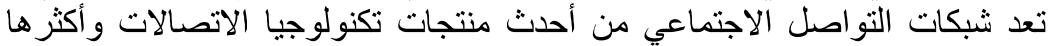

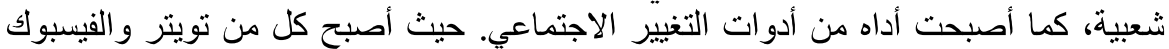

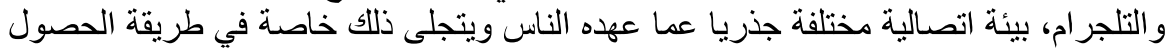
على المعلومات وتبادلها واستهلاكها إذ يميل الأفراد في هذه الثبان ولثبكات إلى التعاون بطريقة فيقة غير

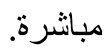

مشكلة الدراسة : مان

إن لوسائل التواصل الاجتماعي تأثير ذو حدين على المعلمين بحسب الاستخدام لها،

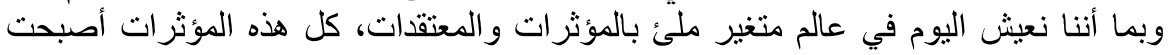

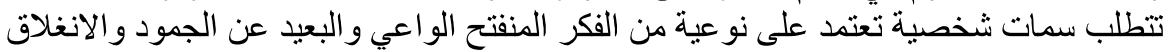

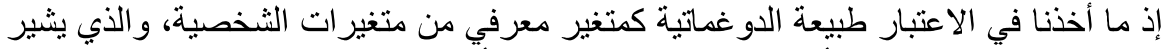

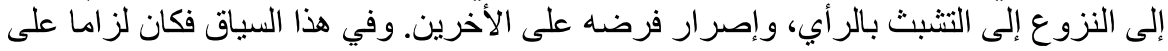

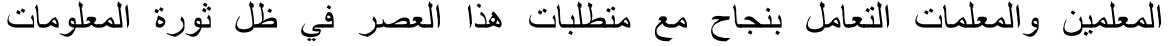




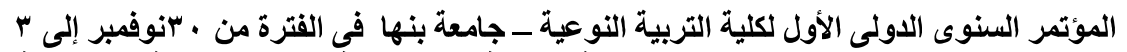

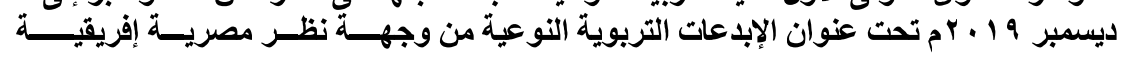

والاتصالات،فلم تعد المشكلة في الحصول على المعلومة بل في اختيار المناسب منها والمهارة

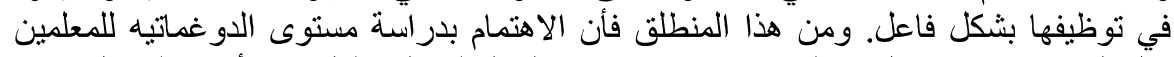

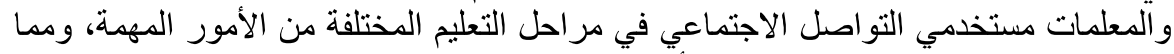

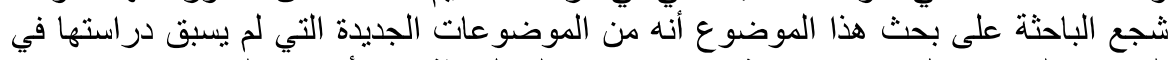

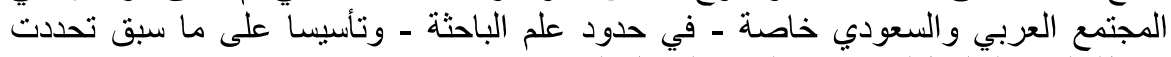

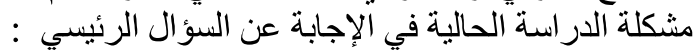

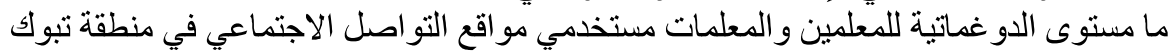
كما يقيسها مقياس الدو غماتية المستخدم في هذه الدرأسة ؟

أهداف الدراسة أنداف

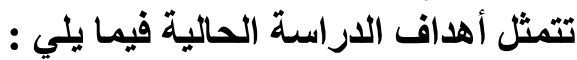

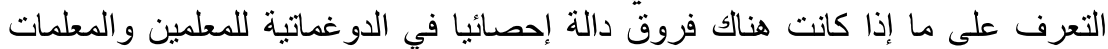

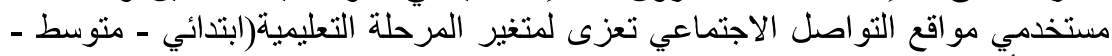

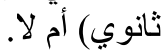

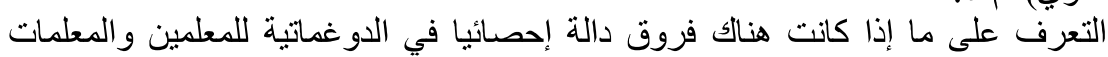

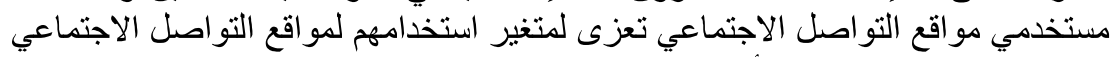

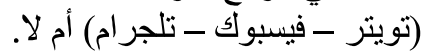

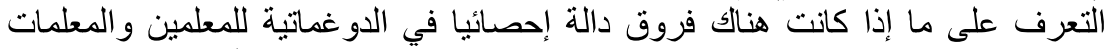

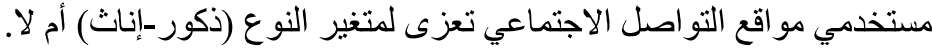

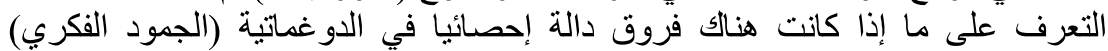

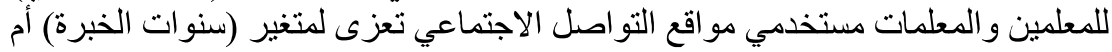

التعرف على ما إذا كانت هناك دالة إحصائيا في الدوغماتية (الجمود الفكري) للمعلمين و المعلمات مستخدمي مواقع التواصل الاجتماعي تلعزى لمتغير العمر أم لا. لا.

$$
\text { وأهمية الدراسة : الأهمية من خلال نتاولها جانبين مهمين هما : }
$$

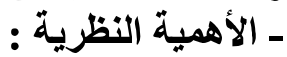

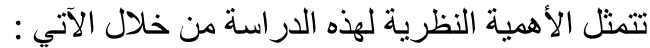

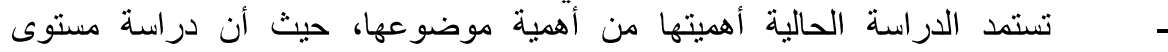

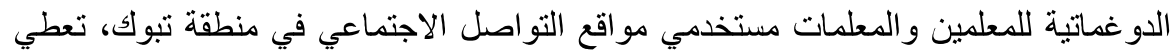
صورة عن شخصية المعلمين و المعلمات مستخدمي مو اقع التواصل الصل الإجتماعي. 


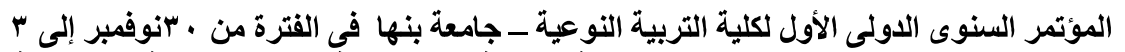

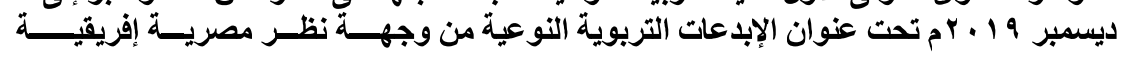

- مالمعمات كما تتمثل في معرفة أثر بعض العوامل الديمجرافية على الدوغماتية للمعلمين

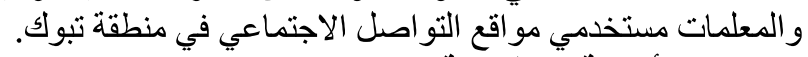
-

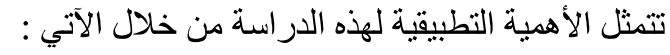

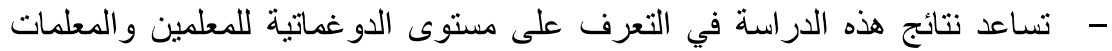

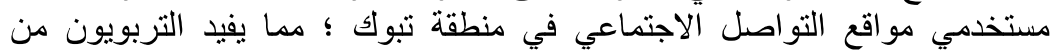

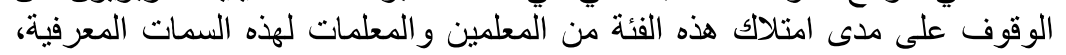
ومن ثم التدخل للتقليل منها.

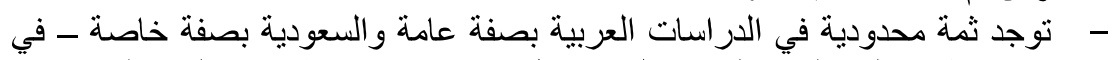

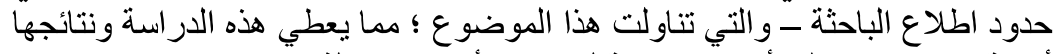
أهمية يمكن من خلالها أن تكون بداية لدر استات أخرى مستقلة.

\section{مصطلحات الدراسة}

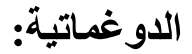

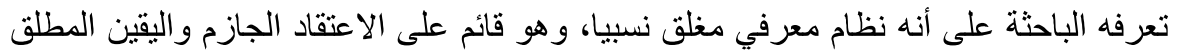

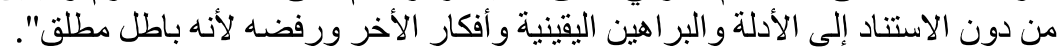

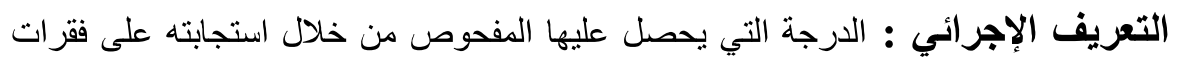
مقياس الدوغماتية من إعداد الباحثة.

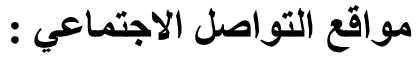

تعرف الباحثة مواقع التواصلُ الاجتماعي " مدى استخدام المواقع الالكترونية المنمثلة في

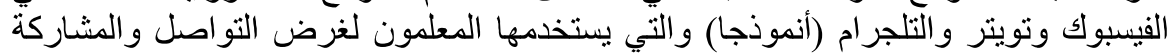

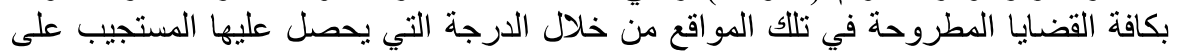

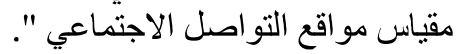

وهم المعلمون والمعلمات العاملات في المدارس الحكومية التابعة لوزارة التربية التعبية المعلمون

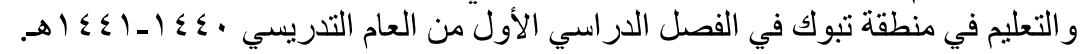

حدود الاراسة ومحدداتها:

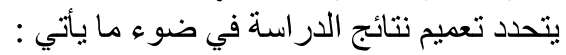

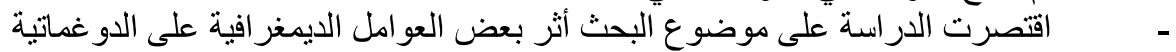
لدى المعلمين و المعلمات مستخدمي مواقع التو اصل البحل الاجتماعي في منطقة تبوكن. 


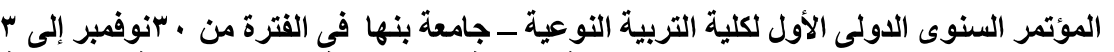

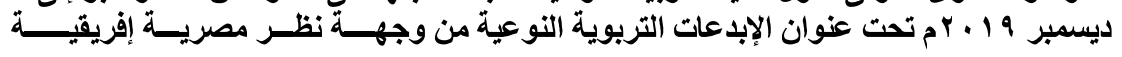

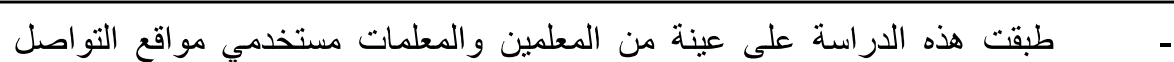
الاجتماعي في منطقة تبوك، وتحدد نتائجها بطريقة اختيار العينة ومدى تمثيلها لمجتمع المعلى الدراسة

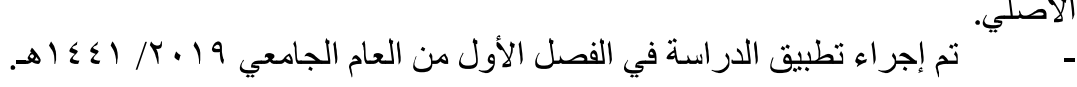
إجراءات الاراسة:

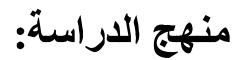
للإجابة عن تساؤلات الدراسة،اتبعت الباحثة المنهج الوصفي.

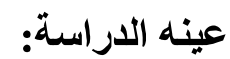

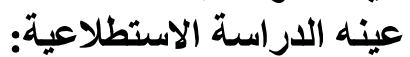

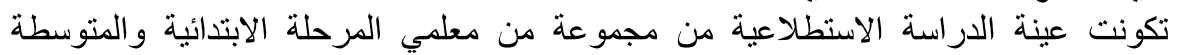

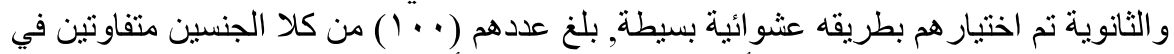

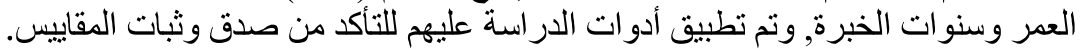

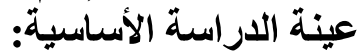
تكونت عينة الدر اسة من (ب9 ه) من لمعلمين و المعلمات متفاوتين في العمر وسنوات الخبرة.

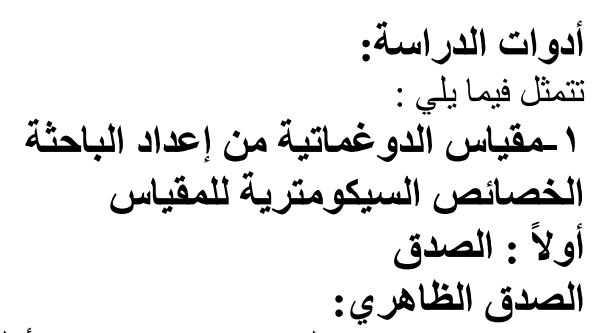

تم عرض المقياس في صورته الأولية علي (9) محكما تم اختيارهم من الخبراء

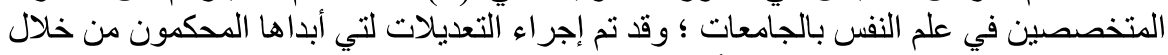

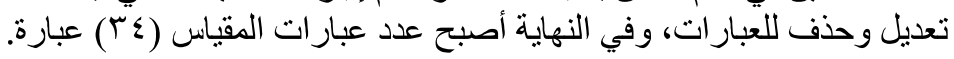

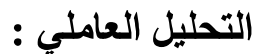
تم إجراء التحليل العاملي Factorial Analysis من الدرجة الأولى لمقياس الداعلى الدوغماتية لدي

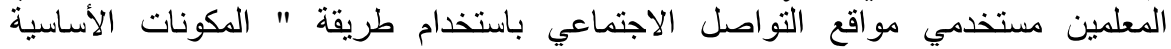
Components Method Principal أفضل طرق التحليل العاملي من حيث الدقة ويستخلص فيها كل عامل أقصى تباين ممكنككما تم 


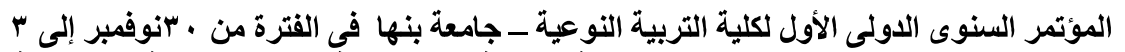

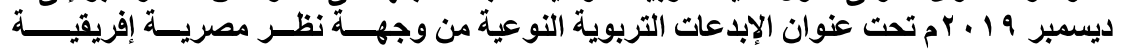

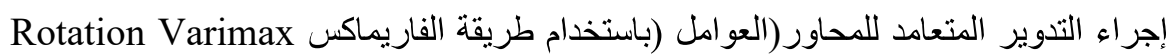

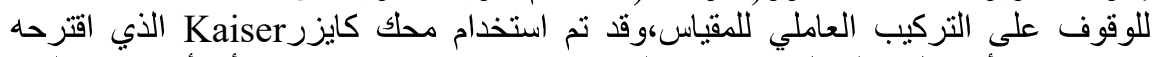

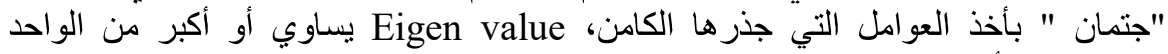

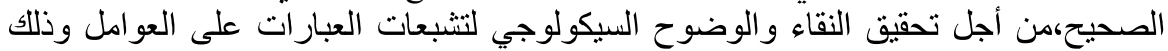

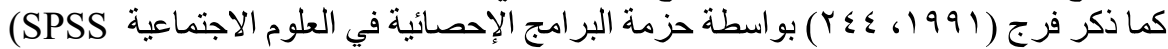

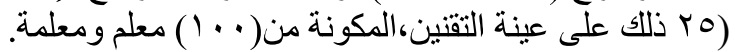

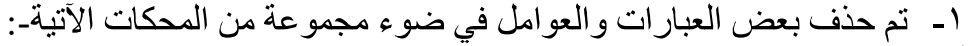

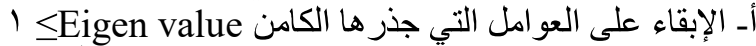

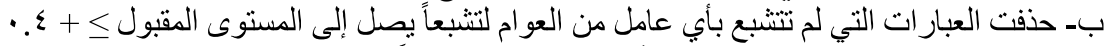

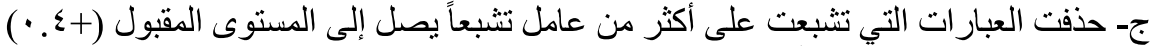

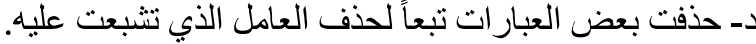

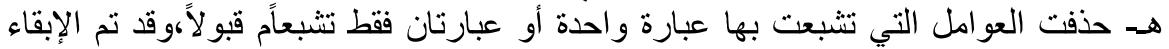

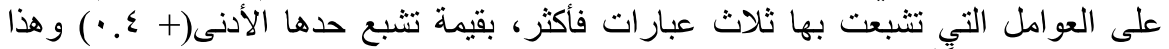

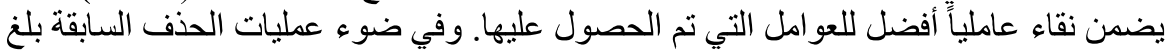

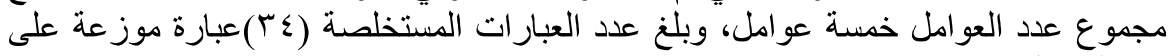

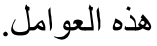

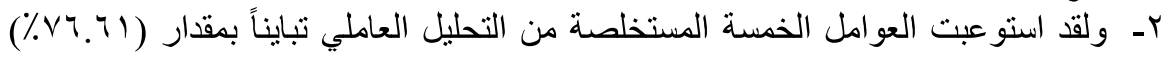

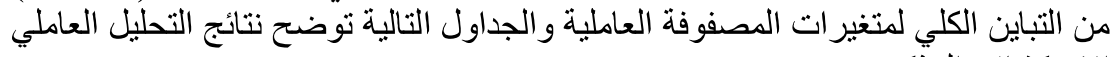

جدول (1) قيم الشيوع والاشتراكات لمقياس الدوغماتية

\begin{tabular}{|c|c|c|c|c|c|c|c|}
\hline قيم الشيوع الو & العبارة & قيم الشيوع الاشتراكات & العبارة & قيم الشيوع الوثتر & العبارة & قالثيم الشيوع أو & العبارة \\
\hline .711 & $r \wedge$ & . AYr & 19 & VA & 1. & . & 1 \\
\hline$T V \varepsilon$ & rq & $\Lambda \cdot \varepsilon$ & $r$. & .701 & 11 & AYE & r \\
\hline VI & $\Gamma$. &.$\wedge \cdot \Lambda$ & YI & .701 & Ir &.$\wedge I V$ & $\Gamma$ \\
\hline ov1 & $\Gamma$ & $7 V 0$ & TY & . Tr. & $\pi$ & $9 Y 4$ & $\varepsilon$ \\
\hline$v r q$ & TY & AYI & Tr & .704 & $1 \varepsilon$ & . 10. & 0 \\
\hline .197 & Tr & Al. & T\& & $V \leqslant 0$ & 10 & $9 \leqslant 7$ & 7 \\
\hline \multirow[t]{3}{*}{$V Y q$} & $\Gamma \varepsilon$ & $V 7$. & ro & VqY & 17 & AYY & $\mathrm{V}$ \\
\hline & & 10. & T & .109 & IV &.$V 94$ & $\Lambda$ \\
\hline & & $V Y I$ & TV & . $1 \varepsilon$ & 11 & $A \cdot 7$ & 9 \\
\hline
\end{tabular}




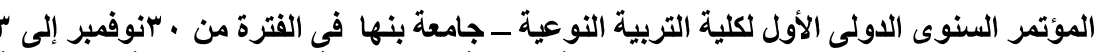

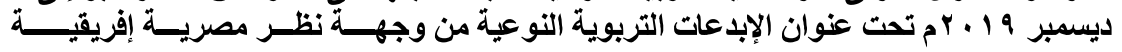

\begin{tabular}{|c|c|c|}
\hline \multicolumn{3}{|c|}{ جدول (r) العبارات ذات التشبعات الدالة علي العامل الأول } \\
\hline التشبع & العبارة & العبارة \\
\hline$\wedge \wedge \uparrow$ & اشعر أن كل ما أتتنع به من مبادئ و أفكار صحيح و غير قابل للتغيير. & r \\
\hline$\wedge \wedge 0_{0}$ & | اعتبر التفكير في القضايا العامة مضيعة للوقت & $r$ \\
\hline ^ฯ. & اعتقد باستمر ار أَن آرائي هي الصحيحة وأن آراء الآخرين خاطئة. & 1 \\
\hline$\wedge \Sigma \vee$ & أكبر أمل لي في الحياة أن أصبح فردا عبقريا & $T$ \\
\hline Ar. & عندما أناقتشالآخرينأتقبل مقاطعتهم & $\varepsilon$ \\
\hline$A \cdot 7$ & | أحرص على التفكير في سعادتي قبل سعادة الآخرين & 0 \\
\hline.$\wedge \cdot r$ & | يغضبني بشدة عدم اعتر اف الفرد بأخطائه & $\mathrm{V}$ \\
\hline $9 . \varepsilon r$ & \multicolumn{2}{|l|}{ الجذر الكامن } \\
\hline YV.VY & \\
\hline \multicolumn{3}{|c|}{ 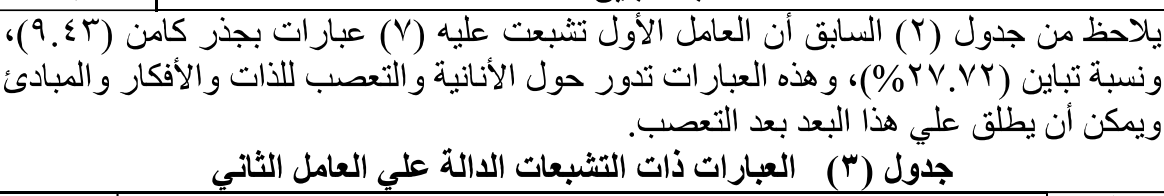 } \\
\hline التشبع & 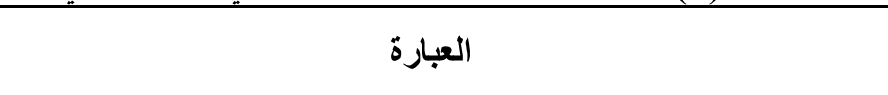 & العبارة \\
\hline.$\wedge 99$ & أسعى لتجربة كل ما هو جديد & 19 \\
\hline.$\wedge \wedge \vee$ & تعدد وجهات النظر في قضايا الفكر الإنساني ضرورة حياتية & 11 \\
\hline.$\wedge T r$ & أعتقد أن الوصول إلى حلول وسط عند اختلاف الآر اء أمر مرغوب في & YI \\
\hline .101 & أسمح بتغيير آرائي إذا كان ذلك جيدا & $r \cdot$ \\
\hline.$\wedge \varepsilon 9$ & أثنعر أن التجديد في الحياة مطلب أساسي & IV \\
\hline.$\wedge \varepsilon \varepsilon$ & على الأفر اد مسايرة ما يحدث في المجتمع من تطورات و تغير ات & 17 \\
\hline.$\wedge r q$ & ينبغي أن يتقبل الفرد أن التغيير سمة من سمات الحياة & 10 \\
\hline & 0.44 & الكامن \\
\hline & $10 . \mathrm{V}$ & التباينة \\
\hline
\end{tabular}

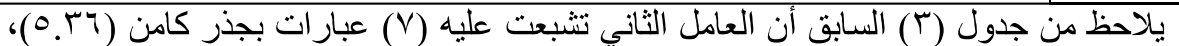

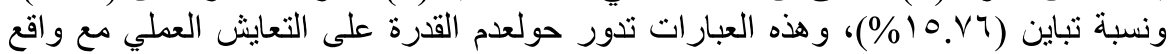

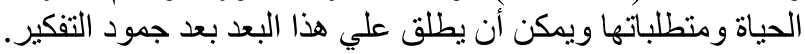




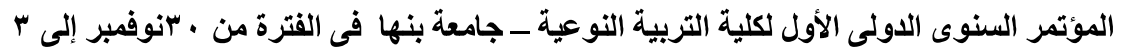

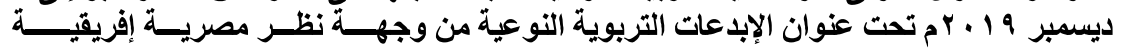

\begin{tabular}{|c|c|c|}
\hline \multicolumn{3}{|c|}{ جدول (ع) العبارات ذات التشبعات الدالة علي العامل الثالث } \\
\hline 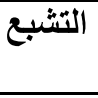 & العبارة & 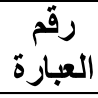 \\
\hline.$\wedge \wedge \mathrm{s}$ & تلفشل المؤسسات التي تسمح لأفر ادها ممارسة حرية الرأي و التعبير وتقبل & 9 \\
\hline.$\wedge \vee 7$ & الأفر اد في هذه الدنيا نو عان فقط،نوع يؤيد الحق والأخر يعارضه & $\Lambda$ \\
\hline . 171 & يستحق من يخالف رأي الجماعة العقاب & $1 \cdot$ \\
\hline$\vee \wedge \wedge$ & أثشعر أن معظم الأفكار التي أصادفها من الآخرين ليست لها قيمة & $1 \varepsilon$ \\
\hline 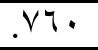 & يجب عدم الإنصات لر أي جميع فئات المجتمع & it \\
\hline$v \varepsilon 1$ & أجد صعوبة شديدة في تقبل التغير ات التي تحدث في المجتمع & 11 \\
\hline$v \cdot 9$ & على الفرد أن يكون له موقف واحد ثابت في الحياة لا يغيره & 14 \\
\hline & $\varepsilon . \vee \top$ & 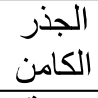 \\
\hline & $1 \varepsilon . \cdots$ & 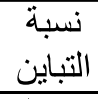 \\
\hline
\end{tabular}

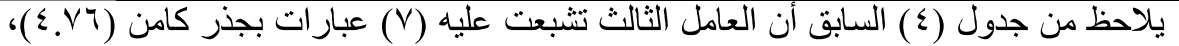

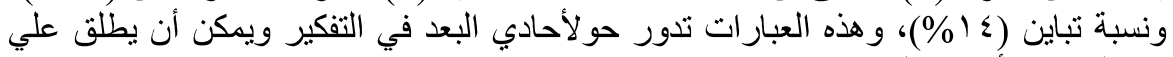

جُدول (0) العبارات ذات التشبعات الألة علي العامل الرابع

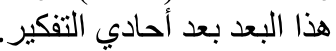

\begin{tabular}{|c|c|c|}
\hline التشبع & 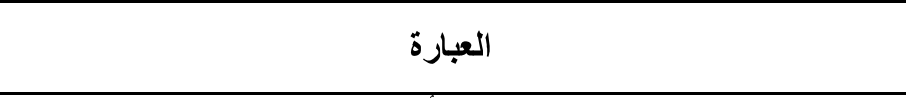 & العبارة \\
\hline$\wedge 9$. & قيم التسامح و المحبة موجودة في كل الأديان وليس في ديني فقط & r \\
\hline 101 & أرفض أي أفكار جديدة يمكن أن تغيير معتقداتي و أفكاري الَّدينية & $r \varepsilon$ \\
\hline . $\wedge \leqslant Y$ & أرفض التحدث و الجلوس مع من يخالف ديني & $r \cdot$ \\
\hline . $\wedge$ ^ᄉ & لا أمانع من تبني الأفكار العقلانية للأديان الأخرى & rr \\
\hline A1 & هناك جانب خير في كل إنسان بغض النظر عن معتقدات دينه ومبادئه & rq \\
\hline Vor & يجب معاقبة أي شخص يحاول أن يجادلني بشأن معتقداتي الدينية & rA \\
\hline \multirow[t]{3}{*}{$V \varepsilon \varepsilon$} & أرفض التحدث و الجلوس مع من يخالف ديني & $r$. \\
\hline & $r . \mu \Lambda$ & الكامن \\
\hline & 9.95 & التباين \\
\hline IrA & 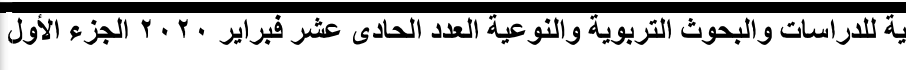 & \\
\hline
\end{tabular}




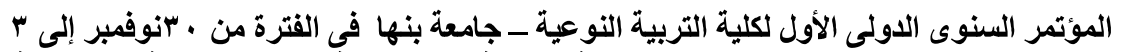

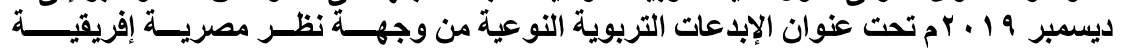

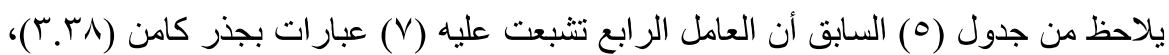

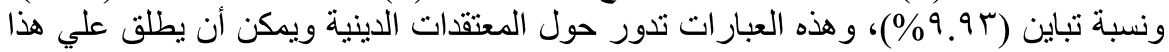

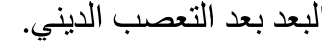
جدول (†) العبارات ذات التشبعات الدالة علي العامل الخامس

\begin{tabular}{|c|c|c|}
\hline التشبع & 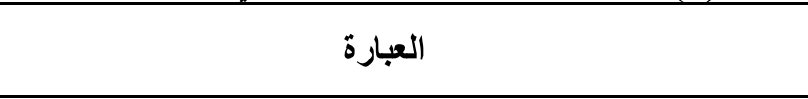 & العبارة \\
\hline.$\wedge \wedge 0$ & تكمن قيمة الفرد بمبادئه العظيمة وما يؤمن به من قضايا & ry \\
\hline.$\wedge \vee q$ & أرى أن الحوار بين الحضار ات غير مجدي & T乏 \\
\hline $.10 \mathrm{~V}$ & لا أحترم الفرد الذي يصر على آرائه الخاطئة & rt \\
\hline$. \wedge \leq 7$ & الحكم على أمر ما يكون صائبا إذا وافق آر اء من تحترمهر & ro \\
\hline.$\wedge r_{T}$ & المبادئ و القيم و المعتقدات ألوع الذين يخالفوننا في الر أي يعد تخليا عن & TV \\
\hline \multirow[t]{3}{*}{.$\vee 9 \vee$} & أكره بعض الأفر اد بسبب مبادئهم وآرائهم المعلنة & rt \\
\hline & r.Ir & الكامن \\
\hline & 9.19 & التباين \\
\hline
\end{tabular}

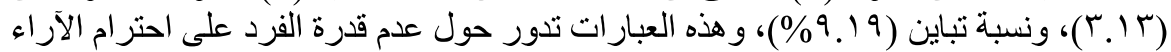

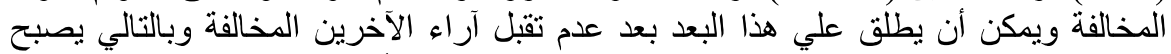

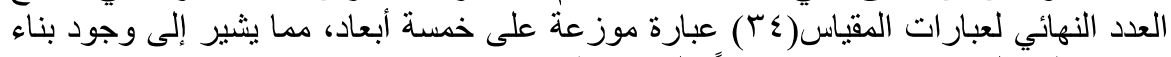

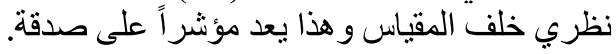

الاتساق الاخلي: عبارة من عبار ات المقياس والدرة الآن الكلية للبعد الذي تنتمي إليه. 


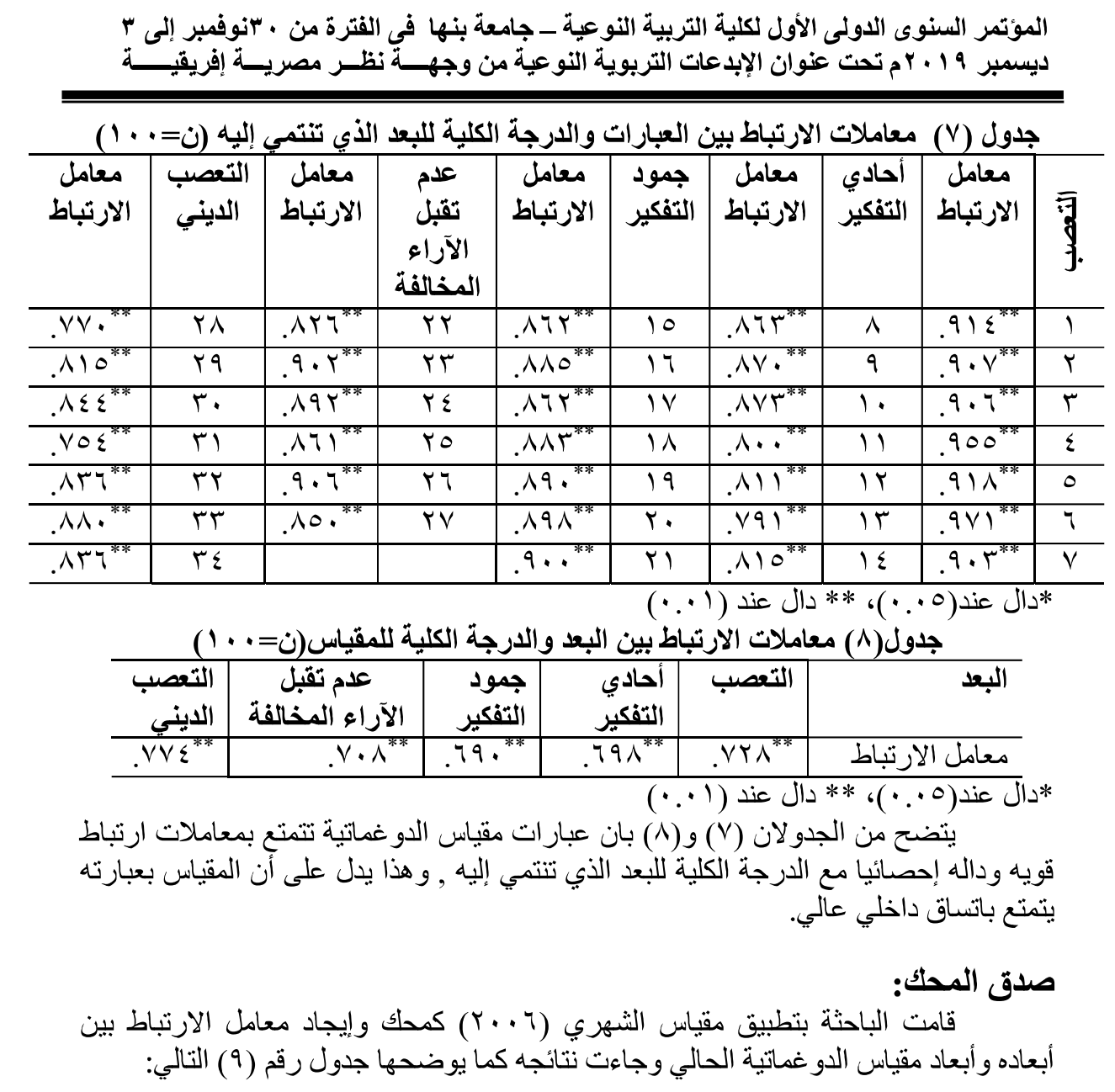

$1 T$.

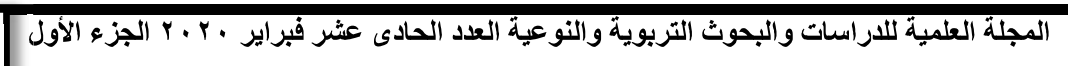




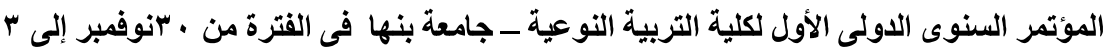

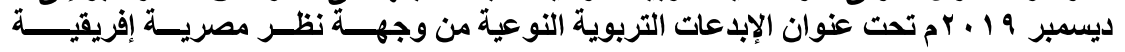

\begin{tabular}{|c|c|c|c|c|c|c|}
\hline \multicolumn{7}{|c|}{ جدول (9) معاملات الارتباط بين المحك و المقياس الحالي } \\
\hline المجموع & الديني & الآراء تقبل & التفكيرد & ألتفكير & التعصب & \\
\hline- & $. \wedge \vee)^{* *}$ & - & - & - &.$\vee \wedge \varepsilon^{* *}$ & الثخصصي \\
\hline- &.$V V V^{* *}$ & - & - &.$\wedge \wedge r^{* *}$ & - & أحادي التفكير \\
\hline- &.$\wedge \vee Y^{* *}$ & & Aro** & - & - & جمود التفكير \\
\hline- & $. \wedge 1 .^{* *}$ &.$\wedge 19^{* *}$ & - & - & - & رفض الآراء \\
\hline.$\wedge 0 \Lambda^{* *}$ & - & - & - & - & - & 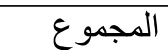 \\
\hline
\end{tabular}

يتضح من الجدول السابق أن الارنباط بين المحك و والمقياس ارتباط قوي ودال إحصائيا

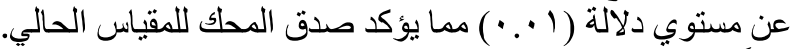
ثانياً : الثبات

: الثبات بطريقه ألفاءكرونباخ Alpha

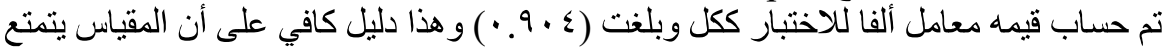

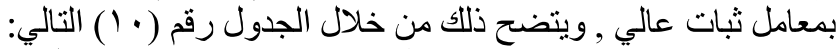
جدول (• 1 ) معامل ألفا كرونباخ لكل بعد والدرجة الكئ الكلية للمقياس

\begin{tabular}{|c|c|c|c|c|c|c|}
\hline الكلي & التعصب & عدم تقبل الآراء & التفكير & ألتفكير & التعصب & البعد \\
\hline$\cdot .9 \cdot \varepsilon$ & $\therefore \wedge \leqslant 0$ & .911 & .947 & .940 & $\cdot 9 \varepsilon \varepsilon$ & ألفا \\
\hline
\end{tabular}

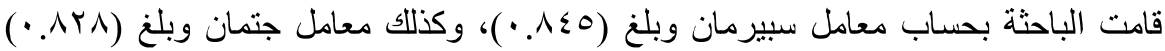

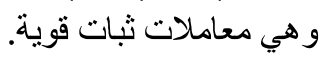

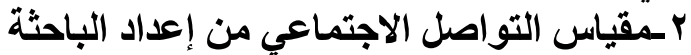

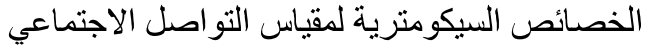

أولاً: صدق المقياس

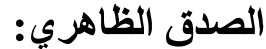

تم عرض المقياس في صورته الأولية علي عدد من المحكمين تم اختيار هم من الخبر اء التخصصين، وقد تم إجراء التعديلات المطلوبة التية. 


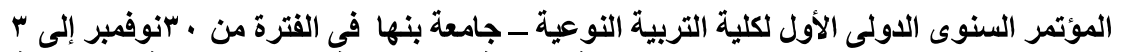

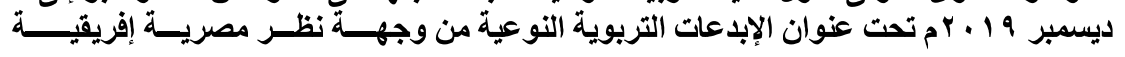

دايسير ثُانياً: الثبات بطات

الثبات بطريقة اعادة التطبيق

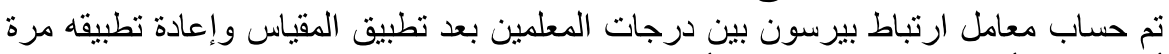

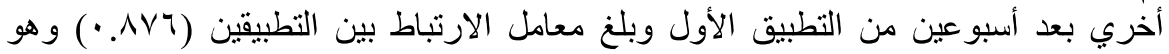
معامل ثبات مرتفع.

نتائج الاراسة الفرض الأول والأي ينص علي: "لا توجد فرق ذات دلالة إحصائية في الدرجة الكلية

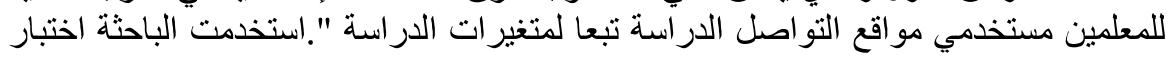

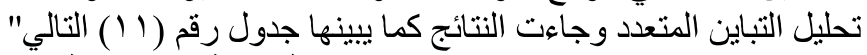

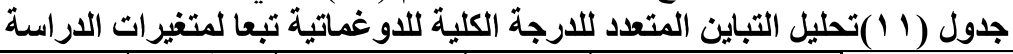

\begin{tabular}{|c|c|c|c|c|c|}
\hline مستوي الدلالة & قيمة ف & المربعات & الحرية & مجموع المربعات & مصدر التباين \\
\hline غير دالة & $r v$. & YA.IVI & 1 & r^.|VI & النوع \\
\hline دالة عند I ... & $1 \varepsilon . \wedge 9 \wedge$ & IIT.ETV & $r$ & หYフォ.AVE & مواقع التواصل \\
\hline غير دالة & $r . r r$ & rYq.AVT & $r$ & $\varepsilon 09 . \vee \leqslant 7$ & العمر \\
\hline غير دالة & rา & $r \cdot .1 \cdot 7$ & r & $\varepsilon \cdot . Y I I$ & الخبرة \\
\hline دالة عند ا +. & $0.0 Y \Lambda$ & $\Sigma Y \cdot .0 \wedge 0$ & $r$ & $\wedge \varepsilon 1.1 \vee$. & المرحلة \\
\hline دالة عند 0. . & $r \ldots 1$ & rYA.rVq & $r$ & 207.001 & التو اصل × النوع \\
\hline دالة عند ا +. & 8.10 & $0 \leqslant r .9 \vee$. & $\varepsilon$ & YIVO.A1. & التواصل ×العمر \\
\hline غير دالة &.$Y \backslash \varepsilon$ & $17 . \mathrm{rVI}$ & $\varepsilon$ & $70.11 \varepsilon$ & التو اصل × الخبرة \\
\hline \multirow[t]{4}{*}{ دالة عند ا •. } & $\Gamma . \wedge \wedge$. & r90.110 & $\varepsilon$ & $111 \cdot . V \varepsilon 1$ & المرحلة > التو > \\
\hline & & $V Y . V V$ & ov1 & $\varepsilon \Gamma \varepsilon \varepsilon \cdot .19 V$ & الخطأ \\
\hline & & & 090 & $0 \ldots 11 \cdot 7 . \cdots$ & المجموع \\
\hline & & & $09 \varepsilon$ & OYT7. TYY & المجمو ع المصحح \\
\hline
\end{tabular}

$$
\text { يوضحها الجدول رقم (r I ) التالي: }
$$




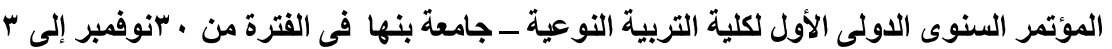

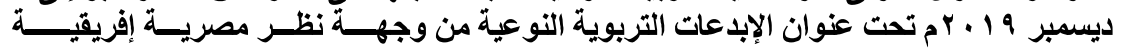

\begin{tabular}{|c|c|c|c|c|}
\hline الالالة & الخطأ & متوسط الفرق & مجموعة المقارنة & الفرق \\
\hline دال عند 0... & $9 Y \varepsilon$ & r.乏.* & توتير & \multirow[t]{2}{*}{ فيسبوك } \\
\hline دال عند ا •. & .919 & $0 . \xi 1^{*}$ & تيلجر ام & \\
\hline دال عند 0 .. & $.9 Y \varepsilon$ & $-r . \varepsilon \cdot{ }^{*}$ & فيسبوك & \multirow[t]{2}{*}{ توتر } \\
\hline دال عند ا •. & ATV & $r \ldots *$ & تيلجرام & \\
\hline
\end{tabular}

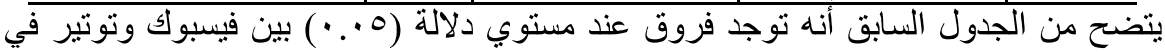

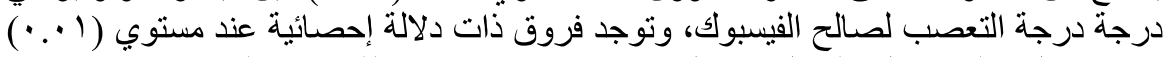

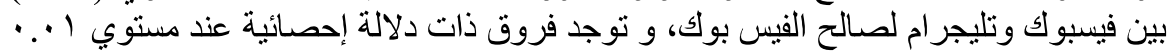

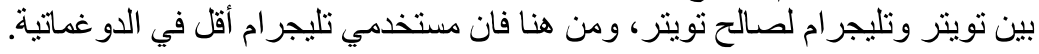

القرض الثاني والأي ينص علي: "لا توجد فرق ذات دلالة إحصائية في درجة التعصب التصب

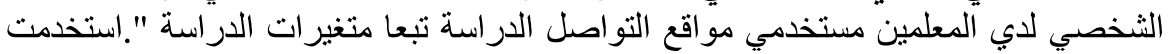

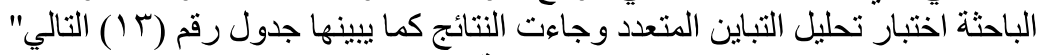

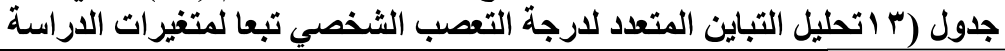

\begin{tabular}{|c|c|c|c|c|c|}
\hline مستوي الالالة & قيمة ف & المربعات & الحرية & المربعوع & مصدر التباين \\
\hline غير دالة & $1 . \wedge 91$ & $11.1 \varepsilon$. & 1 & $11.1 \varepsilon$. & النوع \\
\hline دالة عند ا •.. & IV.VAT & 1. $\_. \wedge$ & $r$ & $r .9 .7 .1$ & مو اقع التواصل \\
\hline غير دالة & $.0 \leqslant V$ & T.YYE & $r$ & $7 . \leqslant \leqslant 9$ & العمر \\
\hline غير دالة غ غ & $\varepsilon r q$ & T.010 & r & $0.1 \mathrm{~V}$. & الخبرة \\
\hline غير دالة & r.AYI & $17.7 Y Y$ & $r$ & $r T . T \leqslant 0$ & المرحلة \\
\hline دالة عند 0 .. & r.qVร & Tr.乏ाA & $r$ & ร7.AY7 & التواصل × النوع \\
\hline دالة عند 0.. & Y. $\Sigma V \varepsilon$ & $1 \varepsilon .0 V 0$ & $\varepsilon$ & $0 \wedge . r \cdot r$ & التو اصل ×العدر \\
\hline غير دالة & .270 & T.VTq & $\varepsilon$ & $1 \cdot .901$ & التو اصل × الخبرة \\
\hline \multirow[t]{4}{*}{ دالة عند 0.. } & r.org & $1 \leqslant .9 \cdot \varepsilon$ & $\varepsilon$ & 09.715 & التواصل × المرحلة \\
\hline & & 0.194 & ov1 & MTE.0IV & الخطأ \\
\hline & & & 090 & Y17779... & المجموع \\
\hline & & & $09 \varepsilon$ & r9Y1..99 & المجموع المصحح \\
\hline
\end{tabular}




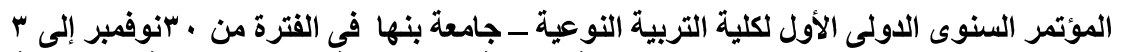

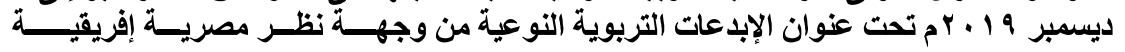

ولمعرفة اتجاه الفروق استخدمت الباحثة اختبار شيفيه للمقارنات البعدية وجاءت نتائجه كما يوضحها الجدول رقم (ع الجاه ( ) التالي: جدول (ع ا ) المقارنات البعدية لتحديد مصدر الفروق(مواقع التواصل الاجتماعي)

\begin{tabular}{|c|c|c|c|c|}
\hline الدلاكة & الخطأ & متوسط الفرق & مجموعة المقارنة & مصدر الفرق \\
\hline دالة عند 0. & rov &.$V V^{*}$ & توتير & \multirow[t]{2}{*}{ فيسبوك } \\
\hline دالة عند ا •. & .107 & $1.04^{*}$ & تيلجرام & \\
\hline دالة عند 0. & rov &.$- V V^{*}$ & فيسبوك & \multirow[t]{2}{*}{ تويتر } \\
\hline دالة عند ا •. & . & $V Y^{*}$ & تيلجرام & \\
\hline
\end{tabular}

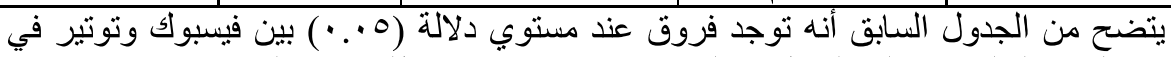

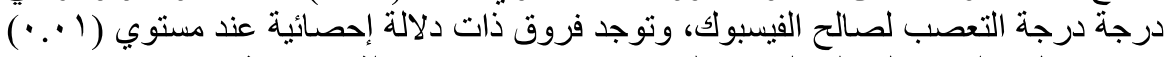

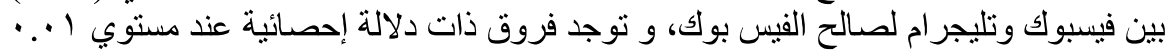
بين تويتر وتليجر ام لصالح توتير ، ومنا هنا فان مستخدمي تليجر ام أقل في التعصب التصن الثخصي.

الفرض الثالث والذي ينص علي: "لا توجد فرق ذات دلالة إحصائية في درجة أحادية

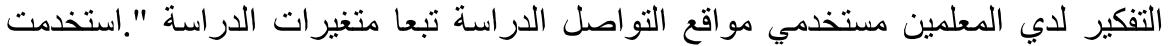

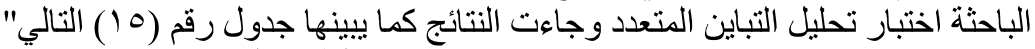

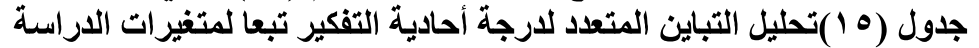

\begin{tabular}{|c|c|c|c|c|c|}
\hline مستوي الدلالة & قيمة & المربعات & الرجرية & المربعات & مصدر التباين \\
\hline غير دالة & .70 & $r \wedge \varepsilon$ & 1 & $r \wedge \varepsilon$ & النوع \\
\hline غير دالة & $1.01 Y$ & $9 . r \vee 9$ & $r$ & $11 . \vee 01$ & مو اقع التواصل \\
\hline غير دالة & $1 . \wedge \leqslant V$ & $1 \cdot .9 \leq 0$ & r & rI. $\wedge \wedge 9$ & العمر \\
\hline غير دالة & .079 & T.rVT & $r$ & $7 . V \leqslant 0$ & الخبرة \\
\hline غير دالة & $1.0 \mathrm{VT}$ & Q.TYI & $r$ & $1 \wedge .7 \varepsilon r$ & المرحلة \\
\hline دالة عند 0.. & E.OTr & rT.109 & $r$ & or.VIV & التو اصل × النوع \\
\hline دالة عند 0.. & $r .19 r$ & $|1.9 Y|$ & $\varepsilon$ & VO.TAr & التو اصل ×العمر \\
\hline غير دالة & $.0 \leqslant \lambda$ & r.YOI & $\varepsilon$ & $1 T . .+4$ & التو اصل × الخبرة \\
\hline \multirow[t]{4}{*}{ دالة عند 0.. } & Y.7. & 10.170 & $\varepsilon$ & $7 r .09$ & التو اصل × المرحلة \\
\hline & & $0.9 \mathrm{TV}$ & ov1 & rrAะ.IVO & الخطأ \\
\hline & & & 090 & YI乏ाYV.... & المجموع \\
\hline & & & $09 \varepsilon$ & rVIV.rAO & المجموع المصحح \\
\hline
\end{tabular}




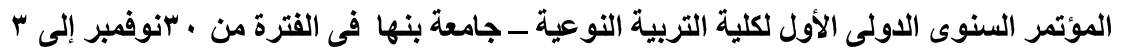

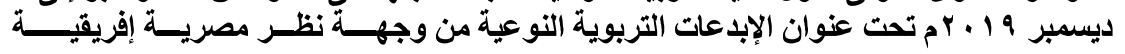

الفرض الرابع والذي ينص علي: "لا توجد فرق ذات دلالة إحصائية في درجة جمود

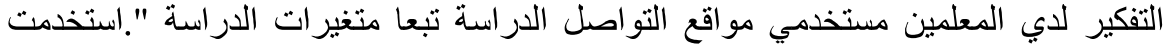

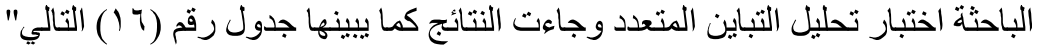

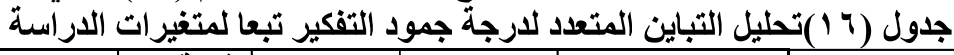

\begin{tabular}{|c|c|c|c|c|c|}
\hline مستوي الدلالة & قيمة ف & المربعات & الحرية & المربعات & مصدر التباين \\
\hline دالة عند 0.. & $0 . Y \wedge 9$ & \&1.0Y० & 1 & $\varepsilon \Lambda .0{ }^{2}$ & النوع \\
\hline دالة عند ا .. & $9.9 Y 7$ & $91 . .91$ & $r$ & $1 \wedge r .197$ & مو اقع التو اصل \\
\hline غير دالة & $1 . Y \wedge V$ & $11 . \wedge 1$. & $r$ & Tr.TY. & العمر \\
\hline غير دالة & .199 & VYI & $r$ & $1 . \varepsilon \leqslant \Gamma$ & الخبرة \\
\hline دالة عند 0.. & r.А৭r & ro.VYO & $r$ & $V 1 . \varepsilon \varepsilon q$ & المرحلة \\
\hline دالة عند ا... & $V . T \leq$ & Tร.รTV & r & IYA.qTr & التواصل × النوع \\
\hline دالة عند I .. & 5.7 .9 & Tr.ITr & $\varepsilon$ & ITr.zqE & التو اصل ×العمر \\
\hline غير دالة & . $9 \varepsilon$ & Y.79\& & $\varepsilon$ & $1 . .2 \vee 0$ & التو اصل × الخبرة \\
\hline \multirow[t]{4}{*}{ غير دالة } & $1.71 Y$ & Iร.V१६ & $\varepsilon$ & 09.117 & الترحلة $\times$ \\
\hline & & $9.18 V$ & ov1 & or\&..Yq9 & الخطأ \\
\hline & & & 090 & $r \ldots 009 . .$. & المجموع \\
\hline & & & $09 \varepsilon$ & T.AT.YAV & المجمو ع المصحح \\
\hline
\end{tabular}

ولمعرفة اتجاه الفروق استخدمت الباحثة اختبار شيفيه للمقارنات البعدية وجاءت نتائجه كما

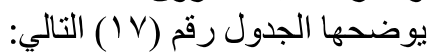
جدول (IV ) المفارنات البعدية لتحديد مصدر الفروق(مواقع التواصل الاجتماعي)

\begin{tabular}{|c|c|c|c|c|}
\hline الالالة & الخطأ & متوسط الفرق & مجموعة المقارنة & مصدر الفرق \\
\hline غير دالة & TrI & . & توتير & \multirow[t]{2}{*}{ فيسبوك } \\
\hline دالة عند ا .. & .519 & $1 . \varepsilon *^{*}$ & تيلجرام & \\
\hline غير دالة & וזT. &.$- Y T$ & فيسبوك & \multirow[t]{2}{*}{ توتر } \\
\hline دالة عند ا ... &.$r \wedge V$ & $1.11^{*}$ & تيلجرام & \\
\hline
\end{tabular}

يتضح من الجدول السابق أنه لا توجد فروق بين فيسبوك وتوتير في درجة درجة جمود التفكير

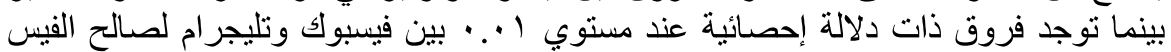

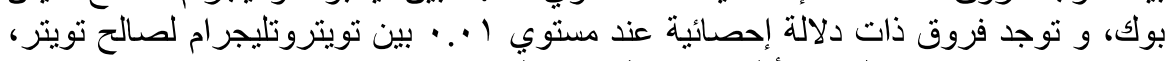
ومنا هنا فان مستخدمي تليجر ام أقل في درجة جمود أتهد التفكير 


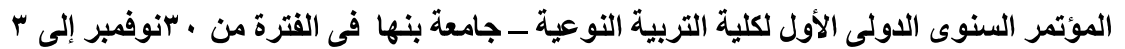

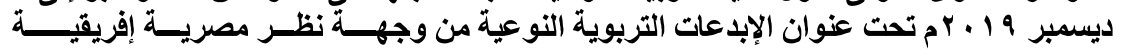

الفرض الخامس والأي ينص علي: "لا توجد فرق ذات دلالة إحصائية في درجة عدم الأبرات

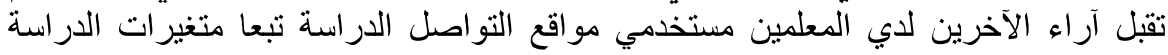

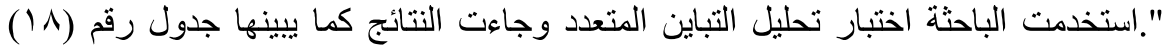

جدول (1 ال)تحليل التباين المتعدد لارجة عدم تقبل آراء الآخرين تبعا لمتغيرات الدراسة

\begin{tabular}{|c|c|c|c|c|c|}
\hline مستوي الدلالة & قَيمة & المربعات & الدرجية & المزبعوع & مصدر التباين \\
\hline غير دالة & $.1{ }^{\prime}$ & I. YOr & $T$ & T. YOY & النوع \\
\hline دالة عند ا ... & $7 . \Sigma \vee \wedge$ & $\sum 7 . Y \wedge r$ & $r$ & 94.077 & مو اقع التواصل \\
\hline غير دالة & $r . V \leqslant 7$ & $19.7 Y 1$ & $r$ & $r q . r \leqslant r$ & العمر \\
\hline غير دالة &.$I T Y$ &.$\wedge V 1$ & $r$ & $1 . V \leqslant r$ & الخبرة \\
\hline دالة عند 0 . . & r.Al. & YV.YYI & $r$ & $0 \leqslant . \leqslant \leqslant Y$ & المرحلة \\
\hline دالة عند 0 .. & $r .9 \leqslant 9$ & YA.YIA & $r$ & $07.2 \Gamma 7$ & التواصل × النوع \\
\hline دالة عند ا ... & r.rqs & rE.YOY & $\varepsilon$ & $9 V . . . V$ & التواصل ×العمر \\
\hline غير دالة & VO. & 0.100 & $\varepsilon$ & $r ! .\{r \mid$ & التو اصل × الخبرة \\
\hline \multirow[t]{4}{*}{ غير دالة } & $1 . r v 1$ & 9.197 & $\varepsilon$ & $r 9.119$ & التو اصل × المرحلة \\
\hline & & $V .1 \leqslant 0$ & ov1 & $\varepsilon . \vee 9 . \wedge 0 Y$ & الخطأ \\
\hline & & & 090 & IVTrVq... & المجموع \\
\hline & & & $09 \varepsilon$ & รT)ร.10ᄉ & المجموع المصحح \\
\hline
\end{tabular}

ولمعرفة اتجاه الفروق استخدمت الباحثة اختبار شيفيه للمقارنات البعدية وجاءت نتائجه كما

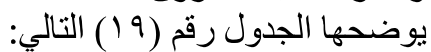
جدول (9 1 ) المقارنات البعدية لتحديد مصدر الفروق(مواقع التواصل الاجتماعي)

\begin{tabular}{|c|c|c|c|c|}
\hline الالاية & الخطاً & متوسط الفرق & مجموعة المقارنة & الفرق \\
\hline 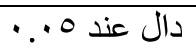 & rAr & $V \wedge^{*}$ & توتير & \multirow[t]{2}{*}{ فيسبوك } \\
\hline دال عند I +. & . rAr & $9 V^{*}$ & تيلجرام & \\
\hline دال عند ه .. & rAN &.$- \vee \wedge^{*}$ & فيسبوك & \multirow[t]{2}{*}{ توتز } \\
\hline غير دالة & ror & .19 & تيلجر ام & \\
\hline
\end{tabular}

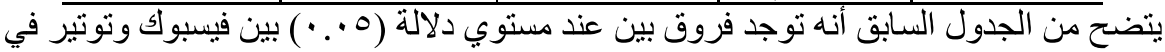

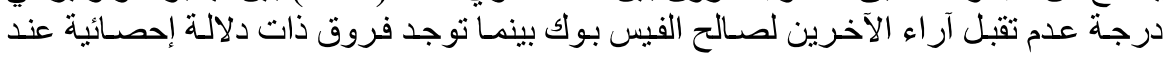




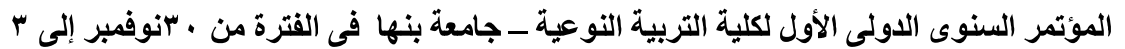

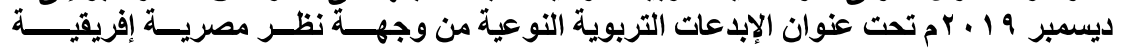

مستوي ا •. • بين فيسبوك وتليجر ام لصالح الفيس بوك ومنـا هنا فان مستخدمي تويتروتليجرام

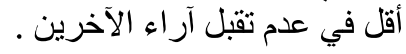

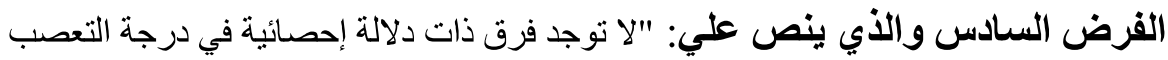

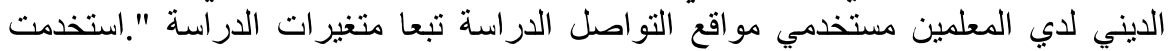

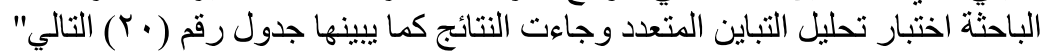

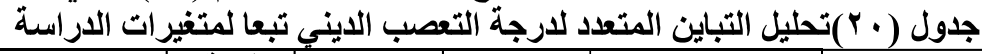

\begin{tabular}{|c|c|c|c|c|c|}
\hline مستوي الدلالة & قَّة & المربعات & الحرية & المربعوع & مصدر التباين \\
\hline غير دالة & 011 & T.OTr & $T$ & T.OTT & النوع \\
\hline دالة عند ا ... & $\Lambda .91 r$ & $0 \varepsilon . \wedge r$ & $r$ & 1.1 .177 & مو اقع التواصل \\
\hline غير دالة & $1 . r \leqslant \wedge$ & $\Lambda.) \vee \wedge$ & $r$ & $17 . r 07$ & العمر \\
\hline غير دالة & .11 & $.7 V$ & $r$ & $.1 \Gamma \varepsilon$ & الخبرة \\
\hline غير دالة & $r . \varepsilon \leqslant Y$ & I乏.AY. & $r$ & rq.7\&. & المرحلة \\
\hline غير دالة & $r \cdot V$ & 1.170 & $r$ & T.VT. & التو اصل × النوع \\
\hline دالة عند ا •. & 0.107 & TI.YAT & $\varepsilon$ & $150.1 \leqslant 7$ & التو اصل ×العمر \\
\hline غير دالة & $V \leqslant V$ & $\varepsilon .0 \mu 1$ & $\varepsilon$ & $11.1 Y_{0}$ & التو اصل × الخبرة \\
\hline \multirow[t]{4}{*}{ دالة عند ا •.. } & T.VTr & rr.09\& & $\varepsilon$ & $9 . r \vee 0$ & التو اصل × المرحلة \\
\hline & & 7.911 & ov1 & $r \leqslant 70.1 \ldots$ & الخطأ \\
\hline & & & 090 & YII $\{\leqslant . .$. & المجموع \\
\hline & & & $09 \xi$ & rq1^.rqV & المجموع المصحح \\
\hline
\end{tabular}

يوضحها الجدول رقم ( البم) التالي:

جدول ( إY) المقارنات البعدية لتحديد مصدر الفروق(مواقع التواصل الاجتماعي)

\begin{tabular}{|c|c|c|c|c|}
\hline الدلالة & الخطأ & متوسط الفرق & مجموعة & مصدر \\
\hline غير دالة & .YTI & $\varepsilon r$ & توتير & \multirow[t]{2}{*}{ فيسبوك } \\
\hline دالة عند ا .. & . YT. & $1 . r \Lambda^{*}$ & تيلجرام & \\
\hline غير دالة & . YTI &.$- \varepsilon r$ & فيسبوك & \multirow[t]{2}{*}{ تويتر } \\
\hline دالة عند ا .. & TrE & $10^{*}$ & تيلجرام & \\
\hline
\end{tabular}




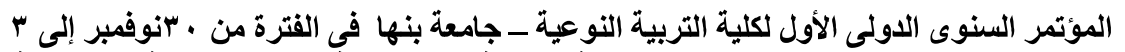

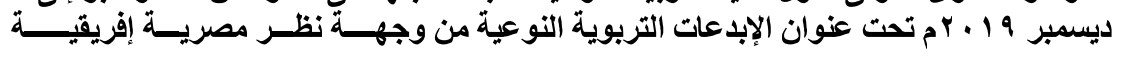

يتضح من الجدول السابق أنه لا توجد فروق بين فيسبوك وتويتر في درجة التعصب الديني بينما

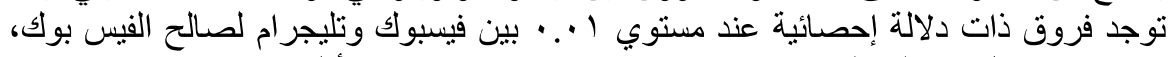

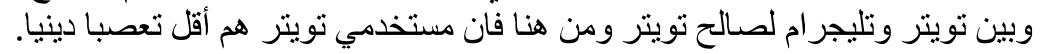

توصلت الدراسة أن مستوي الدوغمانية عندا: عند عينة الدراسة مستخدمي مواقع التواصل تفسير النتائج ومناقشتها:

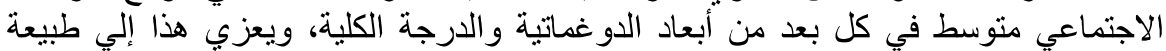

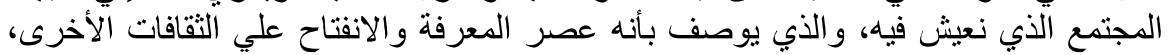

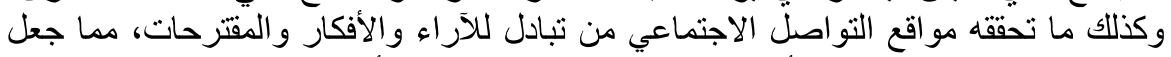

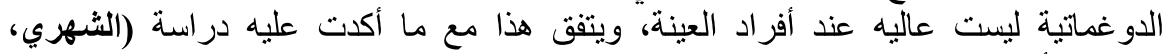

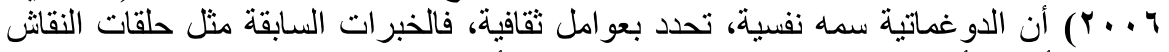

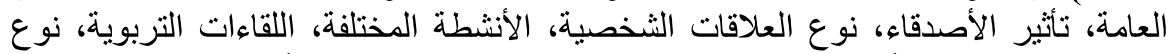

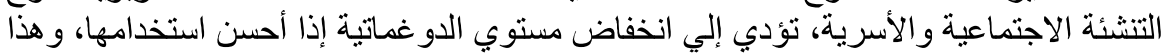

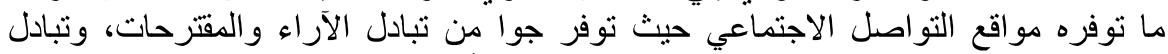

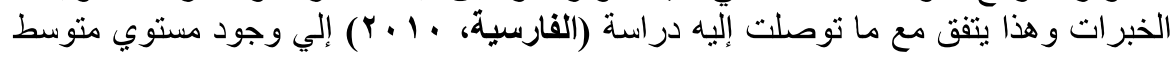
للاوجماتية لدي معلمين التربية الإسلامية بسلطنة الئة درالة عمان.

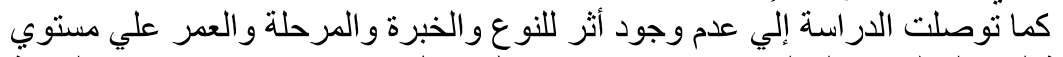

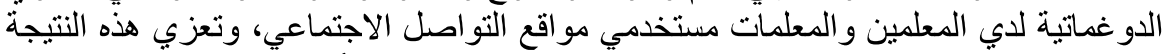

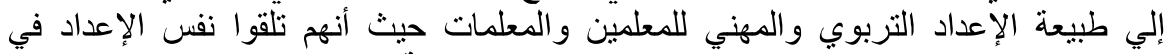

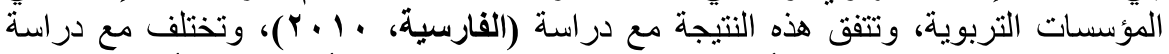

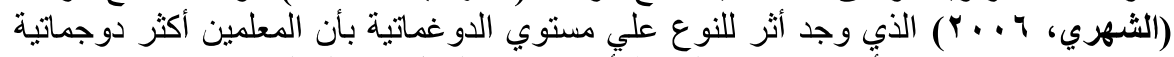

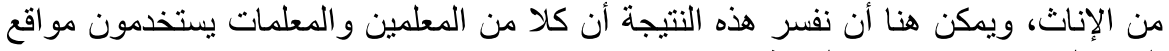
التو اصل الاجتماعي بنفس الكيفية.

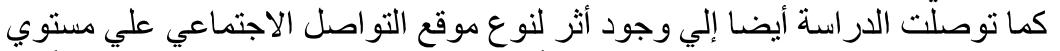

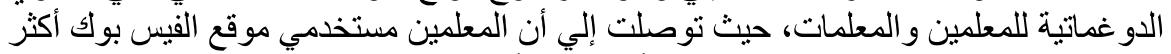

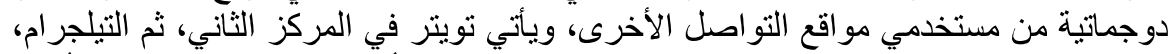

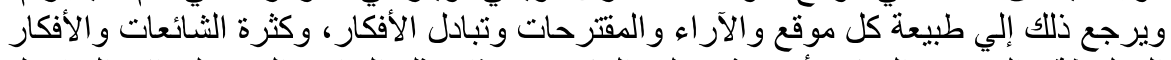

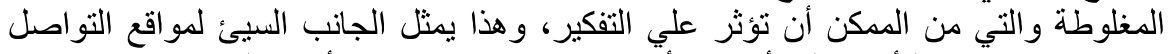

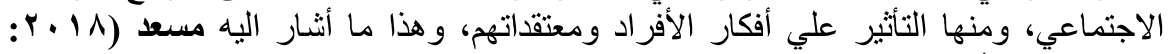

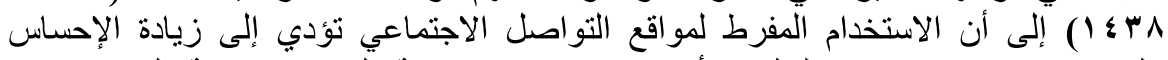

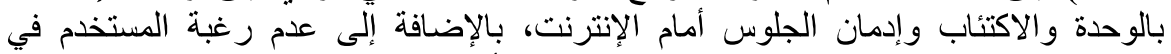

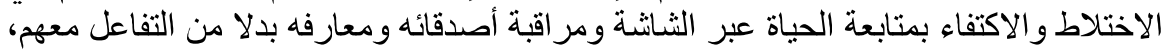




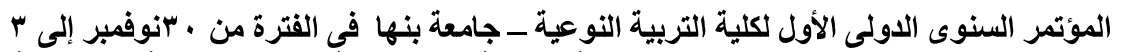

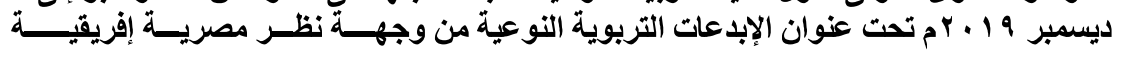

كما أنها تؤدي إلى عدم الثقة في النفس، وزيادة الإحساس بالإخفاقات وتقليل الثعور بالنجات وتاحات،

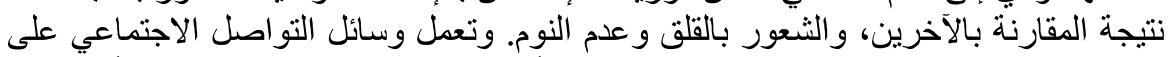

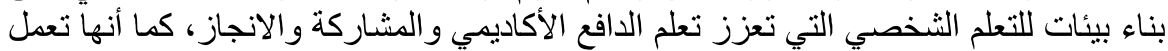

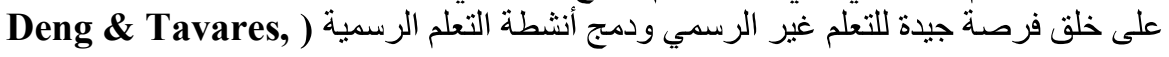

في ضوء نتائج الدراسة، نقدم الباحثة مجموعة من التوصيات على النحو التالي :

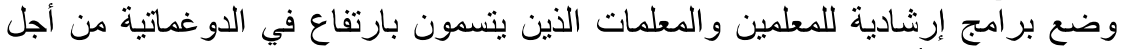
تعديل سلوكهم وأساليب تفكير هم الخاطئ.

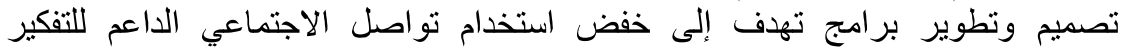

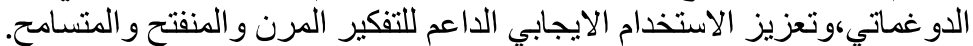

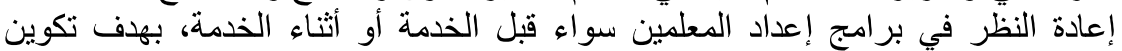

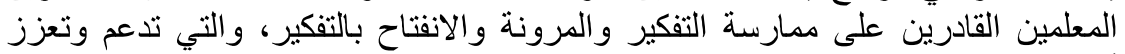

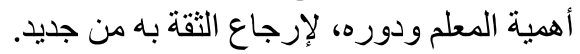
نشر ثقافة توظيف شبكات التّو اصل التهل الاجتماعي بين المعلمين بوجه خاص، وبين جميع فئات

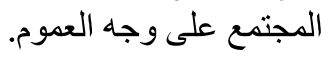

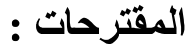

إجراء المزيد من الدراسات والأبحاث حول تحديد مستوى الدوغماتية للمعلمين على اعتبار

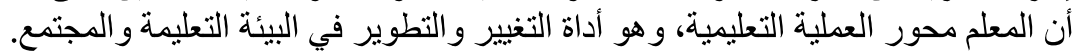

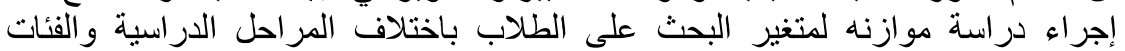

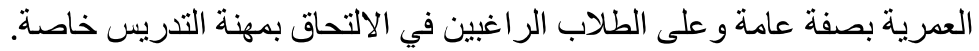

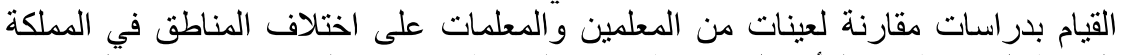

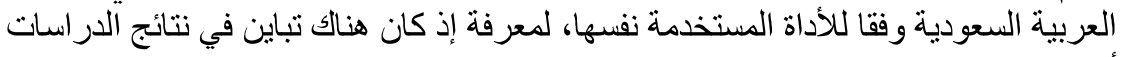

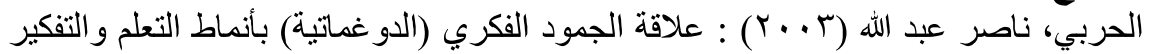

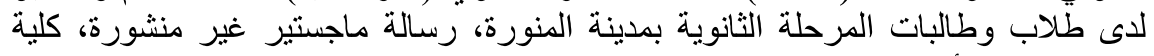
التربية، جامعة أم القرى، مكة المكرمة. 


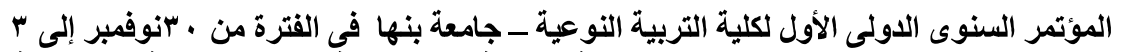

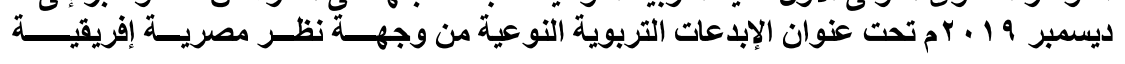

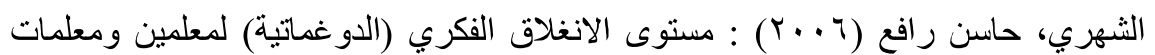

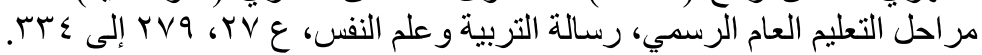

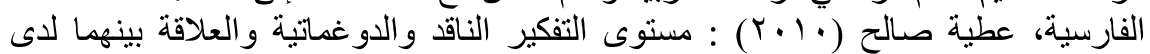

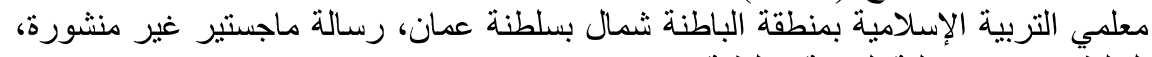

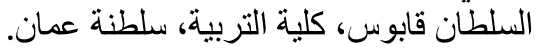

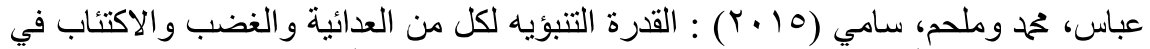

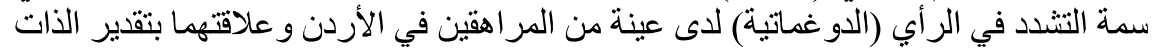

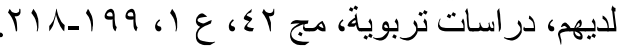

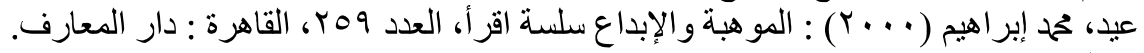
جمال،

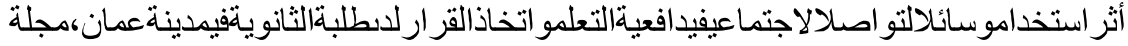

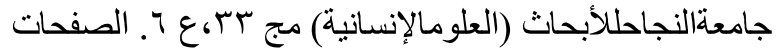

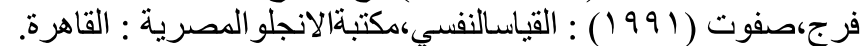

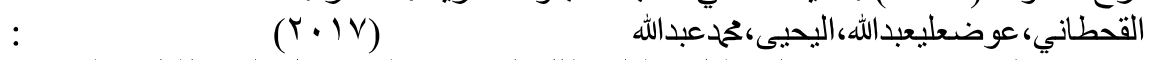

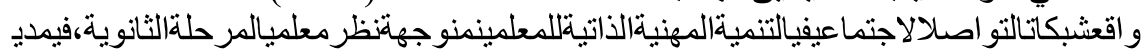

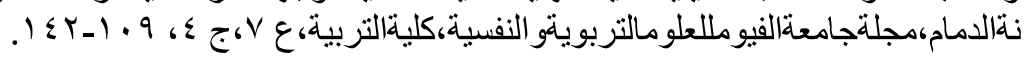

- Deng. L., \& Tavares, N.J. ( $(\cdot 10)$. Exploring university students use of technologies beyond the formal learning context: A tale of two online platforms. Australasian Journal of Educational Technology, r (r), rוr- rrv. 